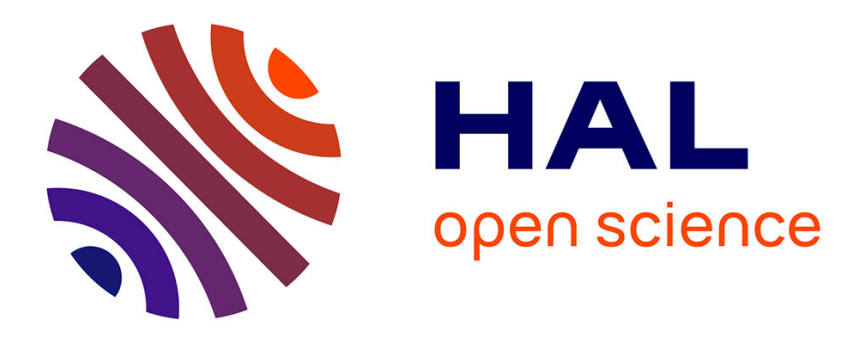

\title{
Poolability and the finance-growth nexus: a cautionary note
}

\author{
Stefano Schiavo, Andrea Vaona
}

\section{To cite this version:}

Stefano Schiavo, Andrea Vaona. Poolability and the finance-growth nexus: a cautionary note. 2006. hal-01065644

\section{HAL Id: hal-01065644 \\ https://hal-sciencespo.archives-ouvertes.fr/hal-01065644}

Preprint submitted on 18 Sep 2014

HAL is a multi-disciplinary open access archive for the deposit and dissemination of scientific research documents, whether they are published or not. The documents may come from teaching and research institutions in France or abroad, or from public or private research centers.
L'archive ouverte pluridisciplinaire HAL, est destinée au dépôt et à la diffusion de documents scientifiques de niveau recherche, publiés ou non, émanant des établissements d'enseignement et de recherche français ou étrangers, des laboratoires publics ou privés. 


\section{The Kiel Institute for the World Economy \\ Duesternbrooker Weg 120 \\ 24105 Kiel (Germany)}

Kiel Working Paper No. 1299

\section{Poolability and the finance-growth nexus: a cautionary note}

by

Stefano Schiavo and Andrea Vaona

October 2006

The responsibility for the contents of the working papers rests with the authors, not the Institute. Since working papers are of a preliminary nature, it may be useful to contact the authors of a particular working paper about results or caveats before referring to, or quoting, a paper. Any comments on working papers should be sent directly to the authors. 


\title{
Poolability and the finance-growth nexus: a cautionary note
}

\author{
Stefano Schiavo* Andrea Vaona ${ }^{\dagger}$
}

September, 122006

\begin{abstract}
The present contribution tests whether countries can be pooled when studying the financegrowth nexus. Overall, our results point toward a 'pragmatic' positive answer, though considerable heterogeneity is present among developing countries.
\end{abstract}

JEL codes: C23, O16

Keywords: poolability, finance, growth

\section{The framework of reference}

This paper investigates the issue of poolability of different countries to study the connection between finance and growth.

The relationship between financial development and growth is a long-standing issue in economics. Recently, empirical research has moved from cross-country studies to the widespread use of panel regressions in accordance with the direction taken by the growth literature as a whole and in order to avoid simultaneity bias (Levine, 2005). One issue that is largely overlooked in most panel studies concerns the poolability of individual series. Levine and Zervos (1993) recognizes the relevance of the problem, but they do not take a stance on it, focusing rather on testing the robustness of the specification of the estimated model.

On the contrary, in the present work we do concentrate specifically on whether series are poolable. In so doing, we follow Baltagi (1981) who very clearly notes that this question has to be answered before the data are pooled, instruments identified and models estimated. If

\footnotetext{
${ }^{*}$ Observatoire Française des Conjonctures Économiques and University of Trento, via Inama 5, Trento 38100 Italy - tel: +39 0461 882115, fax: +390461 882124, email: sschiavo@economia.unitn.it

${ }^{\dagger}$ Kiel Institute for the World Economy and University of Pavia, Department of Economics and Quantitative Methods, Düsternbrooker Weg 120, Kiel 24105 Germany - email: andrea.vaona@ifw-kiel.de

The authors would like to thank Carsten-Patrick Meier for helpful conversations. The usual disclaimer applies.
} 
pooling is in fact rejected, then there will be no scope for a multi-country analysis and policy recommendations will simply be based on wrong premises. Far from being a simple econometric exercise, our contribution highlights the importance of unveiling the priors standing behind econometric estimates, especially when the latter have far reaching policy implications.

\section{Dataset and specification}

We exploit the dataset used by Levine et al. (2000), which is available on-line ${ }^{1}$. It contains data on 74 countries spanning the 1960-1995 period. As customary in growth regressions, data are averaged over non-overlapping five years windows to focus on long-run relationships. We opt for a simple linear specification, which is almost standard in this stream of the literature (see Levine et al., 2000; Calderón and Liu, 2003; Beck and Levine, 2004).

The dependent variable is the growth rate of real per capita gross domestic product (GDP). Regressors include the level of financial development, along with a set of conditioning variables: the level of initial real per capita GDP, educational attainment, government size, openness to trade, inflation, and the black market exchange rate premium. Three alternative measures of financial development are used: (i) liquid liabilities of the financial system divided by GDP; (ii) the ratio of commercial bank assets divided by commercial bank plus central bank assets; (iii) the value of credit extended to the private sector over GDP. The first is a typical index of financial depth; the second measures the degree of involvement of the private sector in providing financial services and hence proxies the maturity of the system; the third excludes credit extended by the central bank and government agencies and also credit issued to public-owned enterprises.

\section{Methods, Results and Conclusions}

Suppose that the matrix of the regressors $\mathrm{X}$ can be partitioned into two parts, $X_{1}$ and $X_{2}$. In our case, $X_{2}$ are the financial indicators taken one at a time and $X_{1}$ are all the other regressors including a constant. We test the poolability of $X_{2}$ only. The restricted model is:

$$
y=\beta_{1} X_{1}+\beta_{2} X_{2}+u
$$

while the unrestricted one is

$$
y=\beta_{1} X_{1}+b_{2} X_{2}^{*}+e
$$

\footnotetext{
${ }^{1}$ http://www.econ.brown.edu/fac/Ross_Levine/Publications.htm
} 
where $y$ is the dependent variable, $\beta_{2}$ and $b_{2}$ are the restricted and the unrestricted vectors of coefficients, $u$ and $e$ are stochastic errors, and $X_{2}^{*}$ is the counterpart of $X_{2}$ for the unrestricted model. Given that we are interested in testing for poolability in an unbalanced setting, $X_{2}^{*}$ is obtained from $X_{2}$ in two steps. First, one obtains its rows as follows:

$$
{ }_{i} X_{2}^{*}={ }_{i} X_{2} \otimes{ }_{i} D
$$

where the $i$ subscript marks the i-th row of a matrix and $D$ is a matrix of country dummy variables. Second, one stacks ${ }_{i} X_{2}^{*}$ in a single matrix to obtain $X_{2}^{*}$.

A review of existing poolability tests is offered in Baltagi (2001). On the basis of a Monte Carlo study, Baltagi (1981) recommends the Roy-Zellner test and the McElroy (1977) criteria. The latter ones do not test the null hypothesis of poolability, but help to choose "pragmatically' between the pooled and the un-pooled estimator on the basis of the lower mean squared error (MSE). In this study we stick to these recommendations. Finally, given that we have an unbalanced dataset we estimated the variance-covariance matrix of the errors relying on Davis (2001).

Results are presented in Table 1. At first we study the behavior of the whole sample: although poolability is always rejected by the Roy-Zellner test, the MSE criteria support it, save in one instance for private credit. The picture is even more robust for the group of developed countries, whilst quite a lot of heterogeneity appears to characterize developing economies. Therefore, pooling seems to be especially problematic for those countries representing the usual target of policy recommendations.

To conclude, while not supported on a purely statistical ground, pooling may indeed be justified from a 'pragmatic' point of view as the additional information granted by a pooled crosssection analysis outweighs the distortion generated by superimposing an identical coefficient across all countries. At the same time, though, our results highlight that the behavior of developing countries is less homogenous. This may be caused by a number of reasons: first, data for developing countries might be of lesser quality; second, substantial heterogeneity across developing countries might actually exist, but we cannot fully capture it due to the relatively short time dimension of the dataset. Our results appear to suggest a critical attitude toward a 'one-fits-all' approach for growth policies and reassess the importance of a country-specific attitude capable to take into account historical, legal and cultural aspects as well (see for instance Rodrik et al., 2005). 


\section{References}

Baltagi, B. (1981), 'Pooling: an experimental study of alternative testing and estimation procedures in a two-way error components model', Journal of Econometrics 17, 21-49.

Baltagi, B. (2001), Econometric Analysis of Panel Data, 2nd edn, John Wiley and Sons, Chichester.

Beck, T. and Levine, R. (2004), 'Stock markets, banks, and growth: panel evidence', Journal of Banking and Finance 28, 423-42.

Calderón, C. and Liu, L. (2003), 'The direction of causality between financial development and economic growth', Journal of Development Economics 72, 321-34.

Davis, P. (2001), 'Estimating multi-way error components models with unbalanced data structures using instrumental variables', Journal of Econometrics 106, 67-95.

Levine, R. (2005), Finance and growth: Theory and evidence, in P. Aghion and S. Durlauf, eds, 'Handbook of Economic Growth', Vol. 1A, Elsevier B.V., The Netherlands, pp. 865-934.

Levine, R. and Zervos, S. (1993), 'What we have learned about policy and growth from crosscountry regressions?', American Economic Review 83(2), 426-30.

Levine, R., Loayza, N. and Beck, T. (2000), 'Financial intermediation and growth: causality and causes', Journal of Monetary Economics 46, 31-77.

McElroy, M. (1977), 'Weaker MSE criteria and tests for linear restricrions in regression models with non-spherical disturbances', Journal of Econometrics 6(3), 389-94.

Rodrik, D., Hausmann, R. and Velasco, A. (2005), 'Getting the diagnosis right', Finance and Development 43, 12-5. 


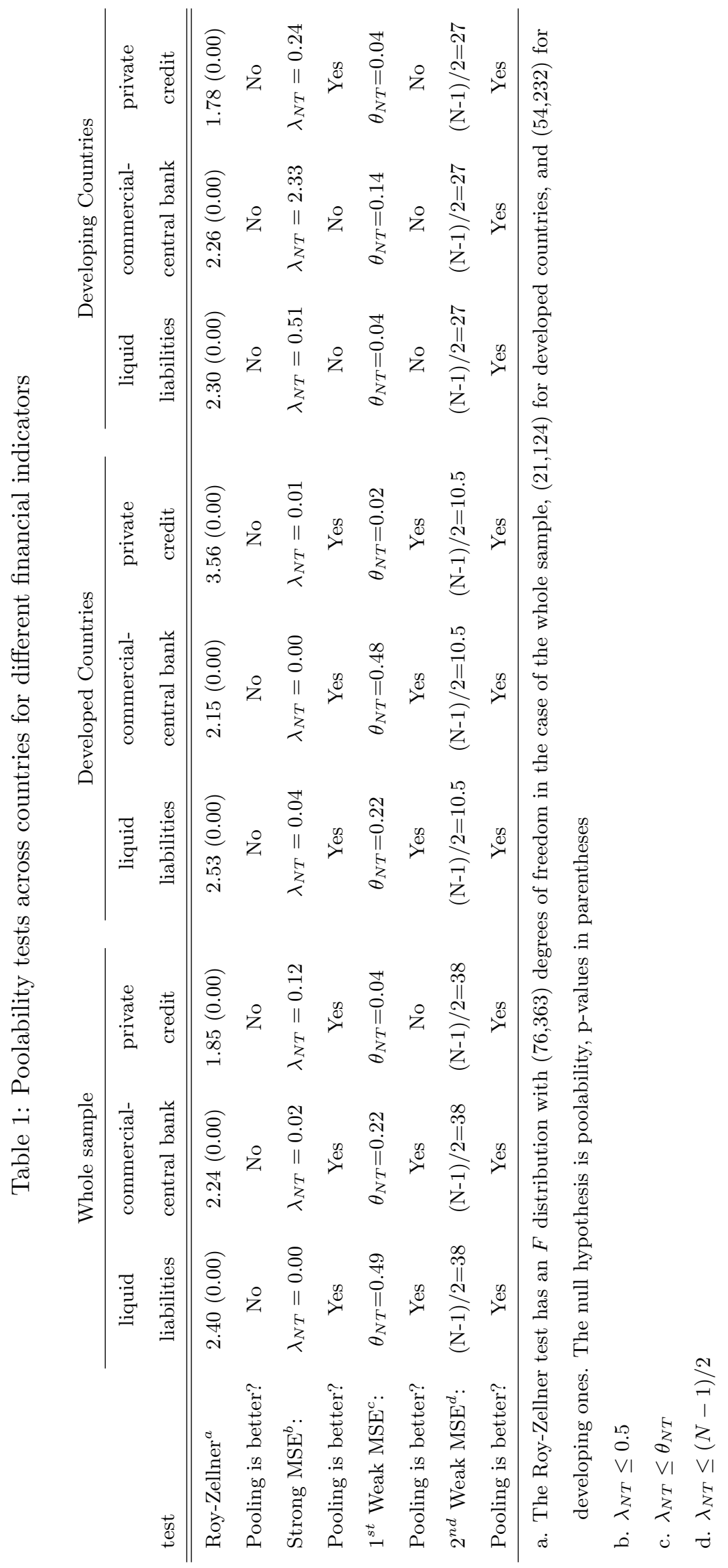

